\title{
Effects of antibiotics and medium supplements on steroidogenesis in cultured cow luteal cells*
}

\author{
J. P. Poff, D.L. Fairchild $\uparrow$ and W. A. Condon \\ Department of Animal and Nutritional Sciences, University of New Hampshire, Durham, \\ New Hampshire 03824, U.S.A.
}

\begin{abstract}
Summary. Corpora lutea were removed from regularly cycling dairy cows, dissociated with collagenase and cultured for 8 or 10 days in Ham's F-12 medium. In Exp. 1 treatment with insulin, or an insulin-transferrin-selenium combination (ITS), increased progesterone production from basal levels on Day 4 of culture to $234 \%(P<0.01)$ above controls on Day 10. LH alone increased progesterone production $45 \%$ above controls on Day $10(P>0.05)$. When LH was combined with insulin or ITS, progesterone production was stimulated to an average of $1802 \%(P<0.01)$ above controls on Day 10 of culture. Transferrin or selenium without insulin did not allow LH to stimulate progesterone synthesis. In Exp. II, LH alone or LH plus gentamicin or penicillinstreptomycin increased progesterone production from basal levels on Day 2 steadily to an average of $468 \%(P<0.01)$ above controls (no antibiotics) by Day 8 of culture. The addition of amphotericin-B, alone or in combination with the other antibiotics, inhibited all LH-stimulated progesterone synthesis, but did not affect basal progesterone levels. We conclude that insulin is essential for maximal steroidogenesis in a bovine luteal cell culture system, and that LH-stimulated progesterone production is inhibited in the presence of amphotericin-B, but is not inhibited by gentamicin or penicillinstreptomycin. The elimination of amphotericin- $\mathrm{B}$, coupled with the addition of insulin to the cell culture system increased the responsiveness of the cells to $\mathrm{LH}$. These culture conditions represent the first report in which LH increased total progesterone production for 10 days, maintaining luteal function in a chemically-defined culture system.
\end{abstract}

Keywords: antibiotics; luteal cells; progesterone synthesis

\section{Introduction}

Numerous workers have maintained long-term cell cultures of granulosa cells (Channing, 1966; Centola, 1979) and luteal cells (Gospodarowicz \& Gospodarowicz, 1972; Stoklosowa \& Stadnicka, 1973 ) by utilizing $10-15 \%$ serum in the culture medium. However, serum contains unknown and varied amounts of hormones and other substances which affect the growth and/or function of endocrine cells in culture. Channing et al. (1976) removed serum from pig granulosa cell cultures and reported enhanced luteinization of the cells with the addition of insulin, cortisol and thyroxin. Reports by Pate \& Condon (1982) and Orly et al. (1980) stated that the addition of serum to culture medium inhibited the response of luteal and granulosa cells to LH and FSH, respectively. Although incapable of responding to gonadotrophins, both cell types are able to respond to cyclic adenosine monophosphate (cAMP) in the presence of serum, suggesting that serum has its inhibitory effect before cAMP accumulation (Orly et al., 1980; Pate \& Condon, 1982).

\footnotetext{
*Reprint requests to Dr W. A. Condon.

†Present address: Department of Dairy Science, Ohio State University, Columbus, Ohio 43210, U.S.A.
} 
Removal of serum necessitates the addition of supplements to meet the physiological requirements of the cells. The most common supplement used is insulin; others include thyroxin, hydrocortisone, cortisol, selenium and transferrin. Antibiotics are also frequently used, the most common being penicillin-streptomycin, gentamicin and the antimycotic amphotericin-B. The objective of this study was to define further the luteal cell culture system reported by Pate \& Condon (1982) by examining the effects of insulin, transferrin, and selenium, the antibiotics penicillin-streptomycin and gentamicin, and the antimycotic amphotericin-B on the steroidogenic response of long-term cultured luteal cells of cows.

\section{Materials and Methods}

Materials. Ham's F-12 culture medium was purchased from KC Biological (Lenexa, KS) and tissue culture flasks (polystyrene, $25 \mathrm{~cm}^{2}$ ) were supplied by Corning (Corning, NY). $N$-2-Hydroxyethylpiperazine- $N^{\prime}$-2-ethanesulphonic acid (Hepes) was provided by US Biochemical Corp. (Cleveland, OH). Bovine serum albumin (BSA) was obtained from Sigma Chemical Corp. (St Louis, MO) and the collagenase, Type I, was purchased from Cooper Biomedical (Malvern, PA). $\left[1,2{ }^{3} \mathrm{H}\right]$ Progesterone was obtained from New England Nuclear (Boston, MA). Insulin, transferrin, selenium, and insulin-transferrin-selenium premix (ITS) are products of Collaborative Research (Waltham, MA). Dialyzed calf serum, gentamicin, penicillin-streptomycin, and amphotericin-B (Fungizone) were obtained from Gibco Labs (Grand Island, NY), and the luteinizing hormone (LH) was NIAMMD-bLH-4 from National Institutes of Health (Bethesda, MD).

Collection and culture of luteal cells. Luteal cell cultures were established as previously reported by Pate $\&$ Condon $(1982,1984)$. Corpora lutea (CL) were removed per vaginam on Day 10 of the oestrous cycle (oestrus $=$ Day 0$)$ from 11 regularly cycling, non-lactating dairy cows of various breeds (5 cows in Exp. I, 6 in Exp. II), and placed into Ham's F-12 culture medium containing $24 \mathrm{~mm}$-Hepes buffer and $14 \mathrm{~mm}$-sodium bicarbonate ( $\mathrm{pH} 7.35$ ) at $4^{\circ} \mathrm{C}$ for transport to the laboratory. Each $\mathrm{CL}$ was weighed, sliced, minced and dissociated at $35^{\circ} \mathrm{C}$ with collagenase $(2000 \mathrm{U} / \mathrm{g}$ tissue) and bovine serum albumin (BSA) $(0.5 \%)$. Every $10 \mathrm{~min}$ the tissue and medium were triturated to facilitate dissociation. The cells were then centrifuged $(100 \mathrm{~g}, 10 \mathrm{~min})$ and washed 4 times with fresh medium containing no BSA. Cells were counted in a haemocytometer and viability was determined by the trypan blue exclusion method (Tennant, 1964).

Tissue culture flasks were pretreated with Ham's F-12 culture medium containing $10 \%$ calf serum for $1 \mathrm{~h}$ at $37^{\circ} \mathrm{C}$. This provided the necessary factors for cell attachment and spreading. The flasks were rinsed twice with fresh medium to remove serum.

Approximately $1 \times 10^{6}$ viable cells were seeded per culture flask in a total volume of $4 \mathrm{ml} \mathrm{Ham}$ 's F-12-Hepes/ bicarbonate medium. Cultures were incubated in a closed system at $37^{\circ} \mathrm{C}$. Culture medium was removed after $24 \mathrm{~h}$, replaced with fresh medium (Day 0 ) and subsequently changed every $48 \mathrm{~h}$ for 10 days (Exp. I) or 8 days (Exp. II). All treatments were performed in duplicate and were added at the start of the culture and with each medium change. Cell numbers were quantitated on Days 2 and 6 using an ocular micrometer square, and steroidogenic activity was expressed per $5 \times 10^{5}$ viable cells.

Experiment I treatments. The control culture medium in Exp. I was Ham's F-12 with Hepes/bicarbonate and included $50 \mu \mathrm{g}$ gentamicin $/ \mathrm{ml}$. Treatment additives included $10 \mathrm{ng} \mathrm{LH} / \mathrm{ml}, 5 \mu \mathrm{g}$ insulin $/ \mathrm{ml}, 5 \mu \mathrm{g}$ transferrin $/ \mathrm{ml}$, and $5 \mathrm{ng}$ selenium/ $\mathrm{ml}$ alone or in combination. These concentrations of insulin, transferrin and selenium are those available in the commercial product ITS (Collaborative Research, Inc.).

Experiment II treatments. The control culture medium in Exp. II was Ham's F-12 with Hepes/bicarbonate and was supplemented with the ITS premix. Treatments included $10 \mathrm{ng} \mathrm{LH} / \mathrm{ml}$, penicillin $(50 \mathrm{U} / \mathrm{ml})$-streptomycin $(50 \mu \mathrm{g} / \mathrm{ml})$, $50 \mu \mathrm{g}$ gentamicin $/ \mathrm{ml}$, and $2.5 \mu \mathrm{g}$ amphotericin $-\mathrm{B} / \mathrm{ml}$, alone or in combination. Antibiotic concentrations were chosen as recommended by Perlman (1979). Controls contained no antibiotics.

Progesterone determination. Decanted medium from each 48 - $\mathrm{h}$ period was stored at $-20^{\circ} \mathrm{C}$ until assayed for progesterone by radioimmunoassay of unextracted samples with anti-progesterone-11-BSA serum (No. 337, Niswender). This antiserum does not cross-react significantly with any abundant steroid in our samples (Gibori et al., 1977). The sensitivity of the assay, as determined by the lower $95 \%$ confidence limit of the maximum binding in the absence of any unlabelled progesterone, was $0.1 \mathrm{ng} / \mathrm{ml}$. The intra-assay and interassay coefficients of variability were $5.3 \%$ and $13.3 \%$ respectively. All standards were assayed in quadruplicate, and all unknowns were assayed in duplicate.

Statistical analysis. Analysis of differences between treatment means was conducted using one-way analysis of variance and Student-Newman-Keuls mean separation procedure. In Exp. I, differences in cell numbers between treatments were analysed by Student's $t$ test. 


\section{Results}

\section{Experiment $I$}

The effects of selenium, transferrin, insulin and ITS on basal progesterone production are shown in Fig. 1. On Day 4 of culture, none of the treatments significantly altered progesterone production and at no time throughout the 10-day culture period did progesterone values in seleniumtreated cultures vary from controls $(P>0.05)$. Transferrin values likewise did not differ from controls, except on Day 10 of culture $(P<0.05)$. Cells cultured in the presence of insulin or ITS consistently produced elevated progesterone amounts as compared to controls. Insulin increased progesterone production significantly on Day $6(P<0.05)$, Day $8(P<0.05)$ and Day 10 $(P<0.01)$, while ITS increased progesterone production significantly on Day $6(P<0.05)$ and on Day $10(P<0.01)$. While all 4 treatments and controls demonstrated a gradual decline of progesterone synthesis, those containing insulin appeared to have a reduced rate of loss of basal progesterone synthesis throughout the 10-day culture.

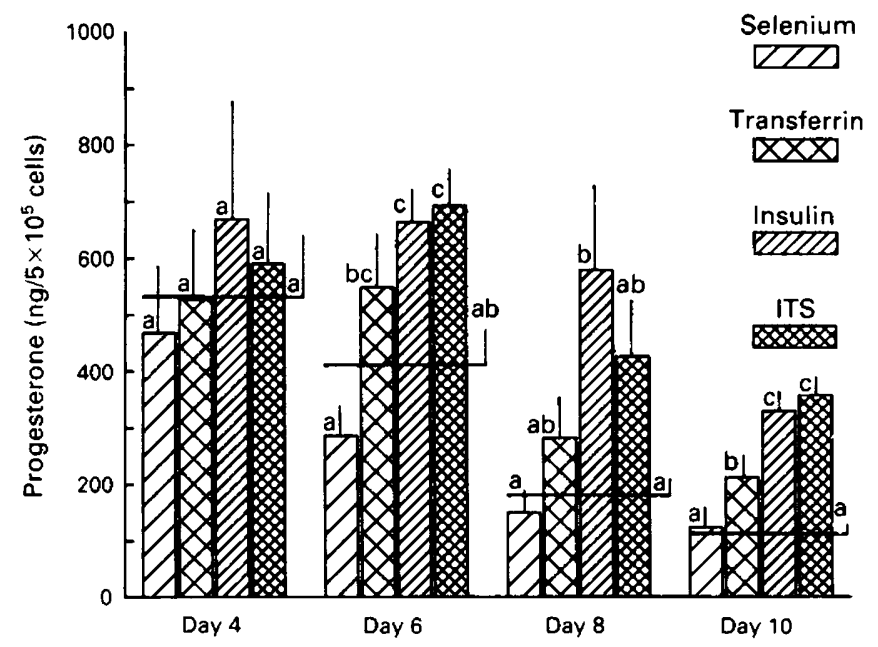

Fig. 1. Effect of medium supplements on progesterone synthesis in LH-free cultures from Day 4 to Day 10. Cells were treated with selenium $(5 \mathrm{ng} / \mathrm{ml})$, transferrin $(5 \mu \mathrm{g} / \mathrm{ml})$, insulin $(5 \mu \mathrm{g} / \mathrm{ml})$, or insulin-transferrin-selenium (ITS). Controls $(-)$ contained no supplements. Bars within day groups with different superscript letters are significantly different (Day 6: $P<0.05$, insulin, ITS; Day 8: $P<0.05$; Day 10: $P<0.05$, transferrin; $P<0.01$, insulin, ITS). Results are expressed as mean \pm s.e.m., for 5 observations.

Figure 2 shows the effect of the same supplement treatments on LH-stimulated progesterone production. Throughout the culture period progesterone values for $\mathbf{L H}$, selenium $+\mathrm{LH}$, and transferrin $+\mathrm{LH}$ were similar to those of controls $(P>0.05)$ and progesterone production declined from Day 4 to Day 10. Although not significantly different $(P>0.05)$ on Day 4 , cultures supplemented with insulin + LH or ITS + LH had progesterone values $100 \%$ and $132 \%$ above those of controls, respectively. On Day 6 of culture, progesterone synthesis increased in response to both treatments and was significantly higher than in controls $(P<0.01)$. This trend continued through Day 8 and, by Day 10 of culture, progesterone production by insulin + LH cultures was $1487 \%$ greater than for controls $(P<0.05)$ and ITS + LH was $2117 \%$ above controls $(P<0.01)$. The insulin + LH and ITS + LH were the only treatments in which progesterone production did not decrease as the time in culture progressed, progesterone synthesis increased by $620 \mathrm{ng} / 5 \times 10^{5}$ cells (insulin $+\mathrm{LH}$ ) and by $1120 \mathrm{ng} / 5 \times 10^{5}$ cells (ITS + LH), from Day 4 to Day 10 of culture. 


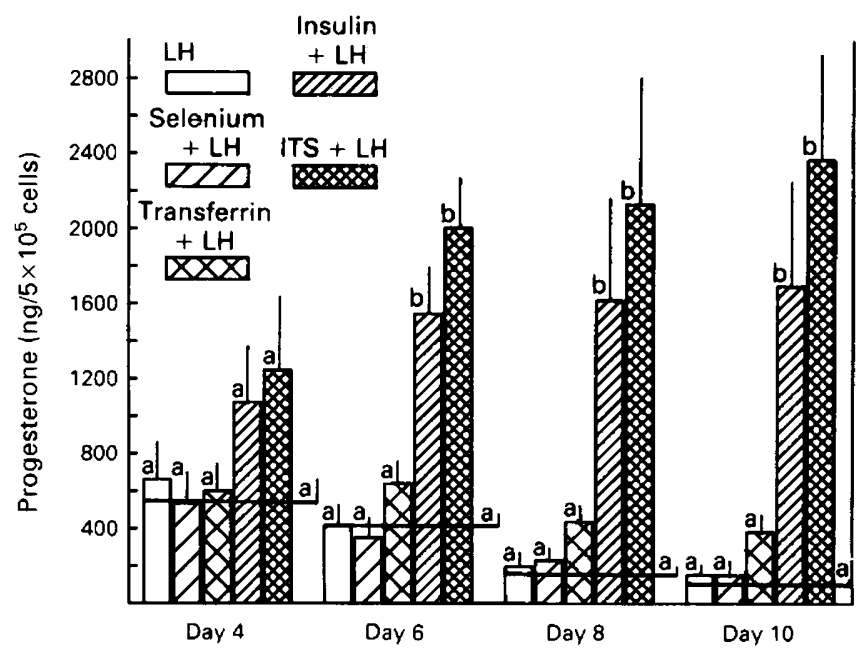

Fig. 2. Progesterone synthesis in LH-containing cultures from Day 4 to 10 . $\mathrm{LH}(10 \mathrm{ng} / \mathrm{ml})$ was added alone or in combination with supplements described in Fig. 1. Bars within day groups with different superscripts are significantly different (Day 6: $P<0.01$; Day 8: $P<0.05$; Day 10: $P<0.05$, insulin + LH $P<0.01$, ITS + LH). Values are mean \pm s.e.m., for 5 observations.

Table 1. Effect of supplement treatments on cell number at Days 2 and 6 of culture of bovine luteal cells

\begin{tabular}{lcc}
\hline & \multicolumn{2}{c}{ Cells/flask $\left(\times 10^{-4}\right)$} \\
\cline { 2 - 3 } Treatment & Day 2 & Day 6 \\
\hline Control & $37.56 \pm 3.36$ & $24.94 \pm 2.24$ \\
LH & $40.64 \pm 3.65$ & $24.90 \pm 2.25$ \\
Selenium & $43.56 \pm 4.79$ & $29.82 \pm 2.54$ \\
Selenium + LH & $43.54 \pm 5.78$ & $29.64 \pm 2.26$ \\
Transferrin & $47.94 \pm 3.91$ & $31.32 \pm 3.22$ \\
Transferrin + LH & $48.18 \pm 4.50$ & $32.00 \pm 3.61$ \\
Insulin & $57.94 \pm 5.55$ & $38.20 \pm 4.04^{* *}$ \\
Insulin + LH & $55.78 \pm 3.96$ & $37.22 \pm 1.99^{* *}$ \\
ITS & $53.22 \pm 6.12$ & $33.34 \pm 3.35^{*}$ \\
ITS + LH & $50.58 \pm 3.85$ & $36.10 \pm 3.65^{*}$ \\
\hline
\end{tabular}

Values are mean \pm s.e.m., for 5 observations.

${ }^{*} P<0.05$ compared to control values; $* * P<0.01$ compared to control values.

Variation in cell number due to treatments is shown in Table 1. On Day 2, there were no differences $(P>0.05)$ in cell numbers between any of the treatment groups, although the cultures supplemented with insulin or ITS (both with and without LH) tended to have higher cell numbers. On Day 6 of culture, only those cultures treated with insulin, insulin + LH $(P<0.01)$ or ITS, ITS + LH $(P<0.05)$ maintained significantly greater cell numbers as compared to controls.

\section{Experiment II}

The effect of various antibiotics on basal progesterone synthesis on Days 4,6 and 8 of culture is 


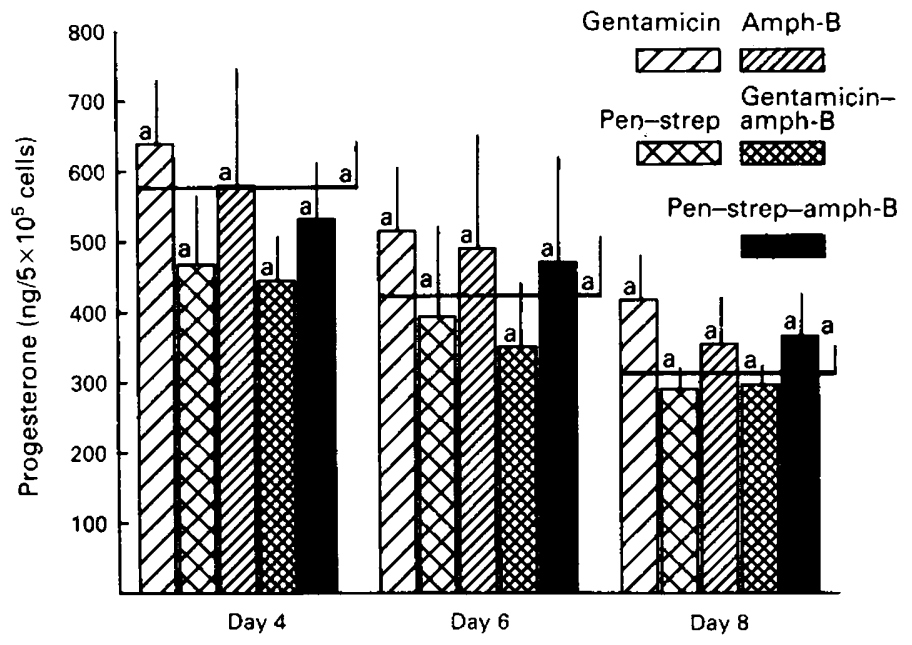

Fig. 3. Effect of antibiotics on progesterone synthesis in LH-free cultures from Day 4 to 8. Cells were treated with gentamicin $(50 \mu \mathrm{g} / \mathrm{ml}$ ), penicillin-streptomycin (pen-strep: $50 \mathrm{U} / \mathrm{ml}-50 \mu \mathrm{g} / \mathrm{ml}$ ), or amphotericin-B (amph-B: $2 \cdot 5 \mu \mathrm{g} / \mathrm{ml}$ ). Controls $(-$ ) contained no antibiotics. All media contained ITS. Bars within day groups with the same superscript letters are not significantly different. Values are mean \pm s.e.m., for 6 observations.

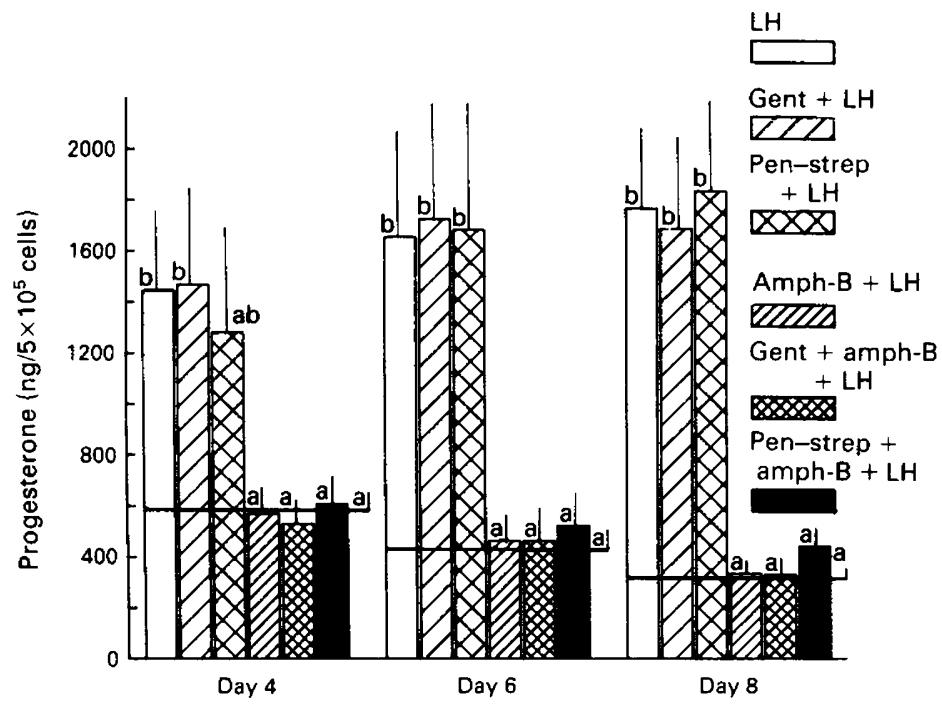

Fig. 4. Effect of antibiotics on progesterone synthesis in LH-containing cultures from Days 4 to 8 . $\mathrm{LH}(10 \mathrm{ng} / \mathrm{ml})$ was added alone or in combination with antibiotics. All media contained ITS. Bars within day groups with different superscripts are significantly different (Day 4: $P<0.05$; Day 6: $P<0.05$, pen-strep + LH; $P<0.01$, LH, gent + LH; Day 8: $P<0.01$ ). Values are mean \pm s.e.m., for 6 observations.

shown in Fig. 3. There were no significant differences $(P>0.05)$ in progesterone production among the antibiotic treatments, alone or in combination, and no treatment differed from control values (no antibiotics). From Day 4 to Day 8 , progesterone production in control cultures declined by an average of $262 \mathrm{ng} / 5 \times 10^{5}$ cells, and all antibiotic-treated cells showed similar declines. 


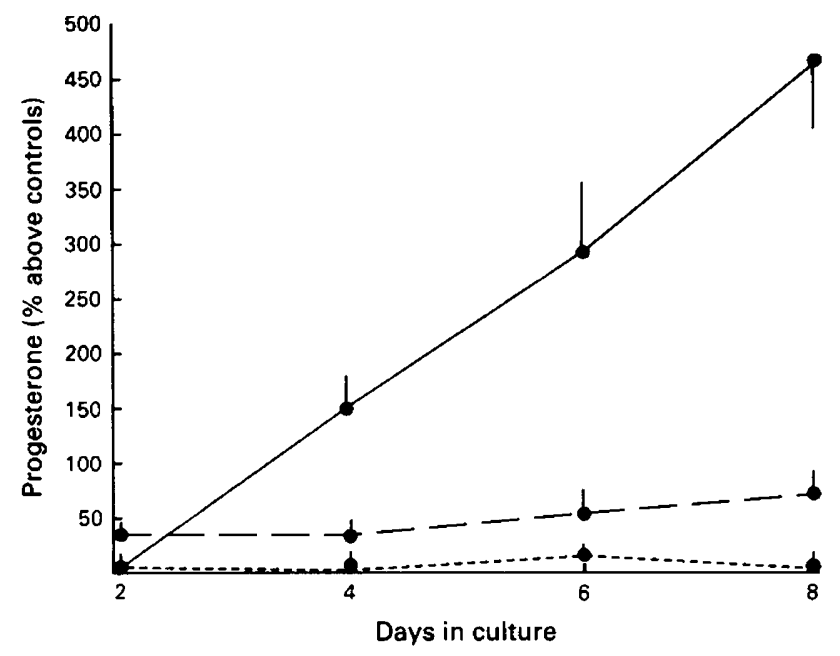

Fig. 5. Responsiveness of bovine luteal cells to $\mathrm{LH}(10 \mathrm{ng} / \mathrm{ml})$ throughout 8 days in culture. LH was added at the beginning of cultures and was replaced with each medium change. ---, Serum-containing (10\%) medium plus amphotericin-B $(2 \cdot 5 \mu \mathrm{g} / \mathrm{ml}), n=8, \cdots$, Serum-free medium plus amphotericin-B $(2 \cdot 5 \mu \mathrm{g} / \mathrm{ml}), n=8$. - - Serum-free and amphotericin-B-free medium, $n=6$. Data for serum-containing and serum-free media from Pate $\&$ Condon (1983).

The effect of adding LH $(10 \mathrm{ng} / \mathrm{ml})$ to the cultures alone or in combination with 1 or 2 antibiotics is shown in Fig. 4. On Day 4 of culture LH and gentamicin + LH increased progesterone synthesis above control values $(P<0.05)$ by approximately $150 \%$. Penicillin-streptomycin $+\mathrm{LH}$ increased progesterone synthesis $123 \%$ above controls, but this stimulation was not significant $(P>0.05)$. On Days 6 and 8 of culture, LH alone or combined with gentamicin or penicillinstreptomycin, continued to increase progesterone synthesis above controls. The average stimulation by these three treatments on Day 8 was $468 \%(P<0.01)$ above control levels. Total progesterone concentrations, rather than decreasing between Days 4 and 8 (as seen in LH-free cultures), increased by an average of $363 \mathrm{ng}$ progesterone $/ 5 \times 10^{5}$ cells. Conversely, when amphotericin-B was added to the cultures with LH (alone or with gentamicin or penicillin-streptomycin), all LH-stimulated progesterone synthesis was abolished, and progesterone values were comparable to those of controls $(P>0.05)$. Amphotericin-B-treated cultures also showed a decline in progesterone synthesis from Day 4 to Day 8.

In Fig. 5, the results from the present experiment are compared to those from a study by Pate \& Condon (1983) in which removal of serum from the medium (containing amphotericin-B) increased LH-stimulated progesterone synthesis from $5 \%$ above controls to $80 \%$ above controls on Day 8 . In the present experiment, removal of amphotericin-B increased stimulation to $468 \%$ above controls on Day 8.

\section{Discussion}

Results from the present study suggest that in a serum-free culture system addition of insulin is essential for LH-stimulated progesterone production and aids in maintenance of basal progesterone synthesis by bovine luteal cells. Several studies have demonstrated that insulin is necessary for pig granulosa cell maintenance and luteinization in culture (Channing et al., 1976; May \& Schomberg, 1981; Otani \& Maruo, 1985; Baranao \& Hammond, 1985). Insulin has also been shown to enhance basal and gonadotrophin-induced progesterone production by bovine luteal cells (O'Shaughnessy 
\& Wathes, 1985), monkey luteal cells (Gulyas et al., 1980) cultured with $10 \%$ serum and in shortterm incubation of rat luteal cells (Tesone et al., 1983; Ladenheim et al., 1984).

In contrast to the findings of O'Shaughnessy \& Wathes (1985), the present study found no significant stimulation of progesterone production by $\mathrm{LH}$ in cultures without insulin. This discrepancy between the two studies is probably due to the fact that O'Shaughnessy \& Wathes (1985) used $10 \%$ serum and, since serum inherently contains insulin, their study contained no truly insulin-free treatments. The addition of insulin, alone or in combination with transferrin and selenium (ITS), resulted in a significant $\mathrm{LH}$ response and facilitated a continuous increase in progesterone levels throughout the 10-day culture period. This increased progesterone synthesis by LH in insulintreated cultures is similar to that observed by May \& Schomberg $(1981,1984)$ in hCG-stimulated pig granulosa cells in culture.

In the present study insulin minimized the loss of cell numbers throughout the culture when compared to control cultures. In granulosa cell cultures, insulin treatment has also been found to increase (Channing et al., 1976) or maintain (May \& Schomberg, 1981) cell numbers.

It is difficult to define a single mechanism of action of insulin on cultured bovine luteal cells, since insulin has several different effects in a number of cell lines. Insulin has been reported to increase cytochrome P-450 cholesterol side-chain cleavage activity in pig granulosa cells (Veldhuis et al., 1983); to induce the biosynthesis of cholesterol side-chain cleavage constituents (Veldhuis $e t$ al., 1986b); to promote increased activity of $3 \beta$-hydroxysteroid dehydrogenase and pregnenolone accumulation in pig (Veldhuis \& Kolp, 1985) and rat (Davoren \& Hsueh, 1984) granulosa cell cultures; to mediate, by specific receptors, enhanced glucose uptake and metabolism in cultured pig granulosa cells (Otani \& Maruo, 1985); to enhance low density lipoprotein binding, internalization, and degradation, contributing to the intracellular cholesterol pool in pig granulosa cells (Veldhuis et al., 1986a); and to stimulate FSH-mediated induction of $\mathrm{LH}$ receptors on pig granulosa cells (May et al., 1980; May \& Schomberg, 1981). It has also been suggested (Adashi et al., 1985) that the stimulatory action of high levels of insulin in pig granulosa cells may be enhanced by crossreactions with the somatomedin receptor, which appears to resemble the insulin receptor (Bhaumick et al., 1981). It is therefore likely that insulin has numerous mechanisms of action in promoting steroidogenesis.

The addition of transferrin and the antioxidant selenium to our cultures had no effect on basal and LH-stimulated progesterone production, or on cell numbers. The results from seleniumsupplemented cultures are in agreement with those of O'Shaughnessy \& Wathes (1985) who reported that several antioxidants, including vitamin $\mathrm{E}$, did not facilitate a significant increase in basal or LH-stimulated progesterone production in cultured bovine luteal cells. This lack of antioxidant effect, as suggested by O'Shaughnessy \& Wathes (1985), may be due to the endogenous presence of the antioxidant $\beta$-carotene in bovine luteal cells.

Although antibiotics can be cytotoxic to cultured cells, there are no published studies of the three antibiotics used in Exp. II on steroidogenesis. This study used recommended and commonly used concentrations of gentamicin, penicillin-streptomycin and amphotericin-B which are not cytotoxic to mammalian cell cultures (Perlman, 1979) to determine the effects of the antibiotics on the steroidogenic ability of bovine luteal cells in culture.

Although we found that $2.5 \mu \mathrm{g}$ amphotericin-B/ml (and $0.25 \mu \mathrm{g} / \mathrm{ml}$; unpublished data) inhibited LH stimulation in luteal cells, there are reports of $\mathrm{LH}$ stimulation when amphotericin-B was present in cell cultures. Channing (1974) supplemented monkey granulosa cell cultures with $20 \%$ serum and $2.5 \mu \mathrm{g}$ amphotericin-B/ml, and found that $\mathrm{LH}$ stimulation was maintained, although no statistical significance was reported. In the study of Pate \& Condon (1982), luteal cells showed a small but significant response to various doses of $\mathrm{LH}(10-1000 \mathrm{ng} / \mathrm{ml})$ when the medium contained $2.5 \mu \mathrm{g}$ amphotericin-B/ml and no serum. Pate \& Condon (1982) reported LH-stimulated $(10 \mathrm{ng} / \mathrm{ml})$ progesterone synthesis of $30 \%$ above control values at Day 11 of culture. This level of stimulation is considerably lower than that in the amphotericin-B-free treatments in the present study. In the study by Pate \& Condon (1983), serum plus amphotericin-B again inhibited the response of the 
luteal cells to LH. In the present experiment, we have shown that the removal of amphotericin-B from serum-free medium increases progesterone production from $80 \%$ above controls (Pate \& Condon, 1983) to $468 \%$ above control values. Further, in the absence of amphotericin-B, absolute levels of progesterone increased from $1446 \mathrm{ng} / 5 \times 10^{5}$ cells (Day 4) to $1765 \mathrm{ng} / 5 \times 10^{5}$ cells (Day 8). This is the first report in which LH-stimulated progesterone synthesis increased with time in a long-term luteal cell culture system.

Amphotericin-B is a polyene macrolide antibiotic. This class of antibiotic is fungicidal and has no effect on bacteria or viruses (Norman et al., 1976). Amphotericin-B acts as an ionophore, combining with sterols (predominantly ergosterol) in the fungal cytoplasmic membrane to form porous channels (Kinsky, 1962; Feingold, 1965). The ability of amphotericin-B to bind to cholesterol and ergosterol has been well documented (De Kruijff et al., 1974; Hopfer et al., 1984). Cholesterol is a major lipid component of cell membranes, interacting with phospholipids within the membrane, modulating membrane fluidity (Whetton et al., 1983). Removal of cholesterol, thus lowering the cholesterol/phospholipid ratio, results in a decrease in membrane fluidity (Whetton et al., 1983). Similar results have been observed after exposure of cellular membranes to amphotericin-B (De Kruijff et al., 1974). Adenylate cyclase activity is inhibited by decreasing membrane fluidity in bovine luteal cells (Milvae et al., 1983) and rat liver plasma membranes (Whetton et al., 1983). Furthermore, amphotericin-B inhibits catecholamine-stimulated adenylate cyclase in pigeon erythrocyte membranes (Puchwein et al., 1974) and fluoride-stimulated adenylate cyclase in rat liver plasma membranes (Dipple \& Houslay, 1979). All of these studies provide strong evidence for the disruption of membrane cholesterol by amphotericin-B, with subsequent alteration of membrane fluidity and adenylate cyclase activity.

In the luteal cell, LH-stimulated progesterone synthesis works through the adenylate cyclase system (Birnbaumer \& Kirchick, 1983). In contrast, Farese (1984) has proposed that basal progesterone synthesis works through $\mathrm{Ca}^{2+}$-dependent protein kinase $\mathrm{C}$. In our study, amphotericin-B abolished LH-stimulated progesterone production, while having no effect on basal progesterone synthesis, supporting the hypothesis that amphotericin-B is exerting its effect at the level of the membrane and altering adenylate cyclase activity.

The results from these studies emphasize the importance of understanding the function and effects of all components in a chemically defined cell culture system.

Scientific Contribution Number 1463 from the New Hampshire Agriculture Experiment Station. We thank Dr G. D. Niswender for the progesterone antiserum and Dr Salvatore Raiti at the National Hormone and Pituitary Program of the NIADDK-LH for the LH. Support for this research was provided by Northeast Regional Project NE-72.

\section{References}

Adashi, E.Y., Resnick, C.E., Svoboda, M.E. \& Van Wyk, J.J. (1985) Somatomedin-C synergizes with folliclestimulating hormone in the acquisition of progestin biosynthetic capacity by cultured rat granulosa cells. Endocrinology 116, 2135-2142.

Baranao, J.L.S. \& Hammond, J.M. (1985) Multihormone regulation of steroidogenesis in cultured porcine granulosa cells: studies in serum-free medium. Endocrinology 116, 2143-2151.

Bhaumick, B., Bala, R.M. \& Hollenberg, M.D. (1981) Somatomedin receptor of human placenta: solubilization, photolabeling, partial purification, and comparison with insulin receptor. Proc. natn. Acad. Sci. U.S.A. 78, $4279-4283$.

Birnbaumer, L. \& Kirchick, H.J. (1983) Regulation of gonadotrophic action: the molecular mechanisms of gonadotropin-induced activation of ovarian adenylyl cyclases. In Factors Regulating Ovarian Function, pp. 287-310. Eds G. S. Greenwald \& P. F. Terranova. Raven Press, New York.

Centola, G.M. (1979) Hormone requirements for longterm maintenance of rat granulosa cell cultures. In Ovarian Follicular and Corpus Luteum Function, pp. 225-233. Eds C. P. Channing, J. M. Marsh \& W. A. Sadler. Plenum Press, New York.

Channing, C.P. (1966) Progesterone biosynthesis by equine granulosa cells growing in tissue culture. Nature, Lond. 210, 1266.

Channing, C.P. (1974) Temporal effects of LH, hCG, FSH and dibutyryl cyclic $3^{\prime}, 5^{\prime}$-AMP upon luteinization of rhesus monkey granulosa cells in culture. Endocrinology 94, 1215-1223. 
Channing, C.P., Tsai, V. \& Sachs, D. (1976) Role of insulin, thyroxin and cortisol in luteinization of porcine granulosa cells grown in chemically defined media. Biol. Reprod. 15, 235-247.

Davoren, J.B. \& Hsueh, A.J.W. (1984) Insulin enhances FSH-stimulated steroidogenesis by cultured rat granulosa cells. Molec. cell. Endocrinol. 35, 97-105.

De Kruijff, B., Gerritsen, W.J., Oerlemans, A., Van Dijck, P.W.M., Demel, R.A. \& Van Deenan, L.L.M. (1974) Polyene antibiotic-sterol interactions in membranes of Acholeplasma laidawii cells and lecithin lysosomes. II. Temperature dependence of the polyene antibiotic complex formation. Biochim. Biophys. Acta 339, $44-56$.

Dipple, I. \& Houslay, M.D. (1979) Amphotericin B has very different effects on the glucagon- and fluoridestimulated adenylate cyclase activities of rat liver plasma membranes. FEBS Letters 106, 21-24.

Farese, R.V. (1984) Phospholipids as intermediates in hormone action. Molec. cell. Endocrinol. 35, 1-14.

Feingold, D.S. (1965) The action of amphotericin B on Mycoplasma laidlawii. Biochem. Biophys. Res. Commun. 19, 261-267.

Gibori, G., Antezak, E. \& Rothchild, I. (1977) The role of estrogen in the regulation of luteal progesterone secretion in the rat after day 12 of pregnancy. Endocrinology 100, 1483-1495.

Gospodarowicz, D. \& Gospodarowicz, F. (1972) Bovine luteal cells in tissue culture. Expl Cell Res. 75, 353-362.

Gulyas, B.J., Yuan, L.C. \& Hodgen, G.D. (1980) Synthesis of progesterone and estradiol by monkey luteal cells in culture: effects of insulin, thyroxin, cortisol and cholesterol with and without hCG. Biol. Reprod. 23, 21-28.

Hopfer, R.L., Mills, K., Mehta, R., Lopez-Berestein, G., Fainstein, V. \& Juliano, R.L. (1984) In vitro antifungal activities of amphotericin B and liposomeencapsulated amphotericin B. Antimicrob. Agents Chemother. 25, 387-389.

Kinsky, S.C. (1962) Nystatin binding by protoplasts and a particulate fraction of Neurospora crassa, and a basis for the selective toxicity of polyene antifungal antibiotics. Proc. natn. Acad. Sci. U.S.A. 48, 1049-1056.

Ladenheim, R.G., Tesone, M. \& Charreau, E.H. (1984) Insulin action and characterization of insulin receptors in rat luteal cells. Endocrinology 115, 752-756.

May, J.V. \& Schomberg, D.W. (1981) Granulosa cell differentiation in vitro: effect of insulin on growth and functional integrity. Biol. Reprod. 25, 421-431.

May, J.V. \& Schomberg, D.W. (1984) Developmental coordination of luteinizing hormone/human chorionic gonadotropin receptors and acute $\mathrm{hCG}$ responsiveness in cultured and freshly harvested porcine granulosa cells. Endocrinology 114, 153-163.

May, J.V., McCarthy, K., Jr, Reichart, L.E., Jr \& Schomberg, D.W. (1980) Follicle-stimulating hormone-mediated induction of functional luteinizing hormone/human chorionic gonadotropin receptors and acute hCG responsiveness in cultured and freshly harvested porcine granulosa cells. Endocrinology 114, 153-163.

Milvae, R.A., Alila, H.W. \& Hansel, W. (1983) Methylation in bovine luteal cells as a regulator of luteinizing hormone action. Biol. Reprod. 29, 849-855.
Norman, A.W., Spielvogel, A.M. \& Wong, R.G. (1976) Polyene antibiotic-sterol interaction. Adv. Lipid Res. 14, 145-170.

Orly, J., Sato, G. \& Erickson, G.F. (1980) Serum suppresses the expression of hormonally induced functions in cultured granulosa cells. Cell 20, 817-827.

O'Shaughnessy, P.J. \& Wathes, D.C. (1985) Characteristics of bovine luteal cells in culture: morphology, proliferation and progesterone secretion in different media and effects of LH, dibutyryl cyclic AMP, antioxidants and insulin. J. Endocr. 104, 355-361.

Otani, T. \& Maruo, T. (1985) Effect of insulin on porcine granulosa cells: implications of a possible receptor mediated action. Acta endocr., Copenh. 108, 104-110.

Pate, J.L. \& Condon, W.A. (1982) Effects of serum and lipoproteins on steroidogenesis in cultured bovine luteal cells. Molec. cell Endocrinol. 28, 551-562.

Pate, J.L. \& Condon, W.A. (1983) Lipoproteins increase progesterone production while serum inhibits $\mathrm{LH}$ response in cultured bovine luteal cells. In Factors Regulating Ovarian Function, pp. 117-121. Eds G. S. Greenwald \& P. F. Terranova. Raven Press, New York.

Pate, J.L. \& Condon, W.A. (1984) Effects of prostaglandin $\mathrm{F}_{2 \alpha}$ on agonist induced progesterone production in cultured bovine luteal cells. Biol. Reprod. 31, 427-435.

Perlman, D. (1979) Use of antibiotics in cell culture media. In Methods in Enzymology, pp. 110-116. Eds W. B. Jakoby \& I. H. Pastan. Academic Press, New York.

Puchwein, G., Pheuffer, T. \& Helmreich, E.J.M. (1974) Uncoupling of catecholamine activation of pigeon erythrocyte membrane adenylate cyclase by filipin. $J$. biol. Chem. 249, 3232-3240.

Stoklosowa, S. \& Stadnicka, A. (1973) Corpus luteum cells grown as monolayers. Experientia 29, 1041-1042.

Tennant, J.R. (1964) Evaluation of the trypan blue technique for determination of cell viability. Transplantation 2, 685-694.

Tesone, M., Ladenheim, R.G., Oliveira-Filho, R.M., Chiauzzi, V.A., Foglia, V.G. \& Charreau, E.H. (1983) Ovarian dysfunction in Streptozotocin-induced diabetic rats. Proc. Soc. exp. Biol. Med. 174, 123-127.

Veldhuis, J.D. \& Kolp, L.A. (1985) Mechanisms subserving insulin's differentiating actions on progestin biosynthesis by ovarian cells: studies with cultured swine granulosa cells. Endocrinology 116, 651-659.

Veldhuis, J.D., Kolp, L.A., Toafi, M.M. \& Strauss, J.F. III (1983) Mechanisms subserving the trophic actions of insulin on ovarian cells: in vitro studies using swine granulosa cells. J. clin. Invest. 72, 1046-1057.

Veldhuis, J.D., Nestler, J.E., Strauss, J.F., II \& Gwynne, J.T. (1986a) Insulin regulates low density lipoprotein metabolism by swine granulosa cells Endocrinology 118, 2242-2253.

Veldhuis, J.D., Rodgers, R.J., Dee, A. \& Simson, E.R. (1986b) The insulin like growth factor, somatomedin$C$, induces the synthesis of cholesterol side-chain cleavage cytochrome $\mathrm{P}-450$ and adrenodoxin in ovarian cells. J. biol. Chem. 261, 2499-2502.

Whetton, A.D., Gordon, L.M. \& Houslay, M.D. (1983) Adenylate cyclase is inhibited upon completion of plasma-membrane cholesterol. Biochem. J. 212, 331-338.

Received 7 April 1987 